\title{
Motilitas dan vitalitas spermatozoa manusia post freezing setelah simpan beku dengan medium TES-Tris yolk citrat yang dimodifikasi dengan jenis kuning telur berbeda
}

\author{
Muhammad Anwar Djaelani \\ Laboratorium Biologi Struktur dan Fungsi Hewan Jurusan Biologi FSM Undip
}

\begin{abstract}
The aim of this research was to examine the possibility of semen cryopreservation using modified TES-Tris yolk citrat (TES-TYC) medium with different egg yolk. Semen fulfilling inclusion criteria with WHO criteria was divided into three groups and the sperm motility and vitality was counted as initial data. The semen was then mixed with TES-TYC medium with chicken egg yolk, TES-TYC medium with duck egg yolk and TES-TYC medium with goose egg yolk then cryopreserved in liquid nitrogen. After one mounth the semen was thawed and recount its sperm motility and vitality. Data obtained showed that the motility and vitality of post freezing sperm cryopreserved with TES-TYC medium with chiken was higher compared to the other medium. It could be concluded that the existenced of chicken egg yolk in TES-TYC medium was better kept sperm integrity during cryopreservation compared with the other medium, hence the existenced of egg yolk as ingredient in TES-TYC medium should be chicken egg yolk.
\end{abstract}

Key words : motilitas dan vitalitas, medium TES-Tris yolk citrat, kuning telur

\section{PENDAHULUAN}

Simpan beku semen (semen cryopreservation) merupakan penyimpanan semen pada suhu sangat rendah dalam nitrogen cair, dengan medium simpan beku tertentu sebagai protektor. Simpan beku semen digunakan untuk menanggulangi masalah dalam reproduksi, baik pada manusia maupun hewan. Hal yang perlu dipertimbangkan dalam simpan beku semen adalah penggunaan medium simpan beku. Medium simpan beku digunakan untuk mempertahankan agar spermatozoa tidak mengalami kerusakan selama simpan beku.

Medium yang digunakan pada simpan beku semen antara lain gliserol, medium ini dapat mempertahankan spermatozoa post freezing $31 \%$ dibanding motilitas spermatozoa pre freezing (Weidel \& Prins, 1987). Medium yang terdiri atas campuran gliserol dan kuning telur ayam dapat mempertahankan motilitas spermatozoa post freezing $49 \%$ dari motilitas spermatozoa prefreezing. Medium lain yang juga banyak digunakan adalah medium TES-Tris yolk citrat (TES-TYC). (Weidel \& Prins, 1987). Penelitian Prins \& Weidel (1986) menunjukkan medium TES-TYC dapat mempertahankan motilitas spermatozoa post freezing $83 \%$ dari pre freezing. Oleh karena itu medium TES-TYC direkomendasikan sebagai cryoprotective medium untuk simpan beku spermatozoa manusia (Weidel \& Prins, 1987 ; Hallack et.al., 1996).

Medium TES-TYC selalu menggunakan kuning telur ayam (Mortimer,1994), namun tidak dikemukakan mengapa kuning telur ayam yang digunakan dan bukan jenis kuning telur yang lain. Kuning telur angsa secara matematis memiliki kandungan gliserol dan kolesterol tertinggi dibandingkan dengan kuning telur bebek atau kuning telur ayam. Gliserol dan kolesterol merupakan komponen penting dalam medium simpan beku sehingga kuning telur angsa dimungkinkan akan lebih baik bila digunakan sebagai bahan baku medium modifikasi TES-Tris yolk citrat (TES-TYC).

Berdasarkan uraian tersebut di atas maka perlu dilakukan penelitian untuk menguji apakah kuning telur dalam medium TES-TYC selain kuning ayam akan lebih baik bila digunakan sebagai bahan baku medium modifikasi TES-Tris yolk citrat (TES-TYC) . Penelitian ini bertujuan menganalisis kemungkinan penggunaan TES-TYC dengan kuning telur selain kuning telur ayam. terhadap motilitas dan vitalitas spermatozoa post freezing.

Struktur spermatozoa mature, terdiri atas kepala dengan akrosom dan nukleus. Bagian 
tengah (midpiece) terdapat mitokondria, sitoplasma, aksonema, dan serabut padat luar. Bagian ekor terdapat aksonema dan selubung fibrosa. Aksonema merupakan struktur kompleks yang terdiri atas 9 pasang mikrotubulus yang saling berhubungan melalui nexin dan berhubungan dengan selubung sentral dari sepasang mikrotubulus sentral melalui jari-jari radial (Neischlag \& Behre, 1996 ; Johnson \& Everitt, 1988).

Dasar struktural gerakan spermatozoa adalah ekor spermatozoa dengan aksonema sentral dan serabut padat luar. Bagian proksimal yang dikenal sebagai bagian tengah dikelilingi oleh mitokondria yang menyediakan energi untuk pergerakan spermatozoa. Sembilan serabut mikrotubulus di bagian luar merupakan unit kontraktil utama sedangkan mikrotubulus di bagian tengah berfungsi sebagai konduktor impuls yang cepat dan menghasilkan gerakan ritmik (Hafez, 1968).

Motilitas merupakan salah satu faktor penting dalam menentukan kualitas spermatozoa. Motilitas sangat menentukan keberhasilan spermatozoa menembus mukus serviks dalam proses fertilisasi. Turunnya motilitas spermatozoa akan berpengaruh pada terjadinya kehamilan (Mortimer, 1994).

Istilah vitalitas spermatozoa mengacu pada istilah viabilitas spermatozoa. Pengujian vitalitas dilakukan bila presentase spermatozoa immotile melebihi $50 \%$ (Anonim,1999). Dengan berkembangnya Inter Cytoplasmic Sperm Injection (ICSI) maka uji vitalitas ini menjadi sangat penting, karena dapat membedakan sel mati dari sel yang hidup yang digunakan sebagai indikator pada prosedur Intra Cytoplasmic Sperm Injection (Girraud et. al., 2000 ; Polcz,1996)

Upaya untuk mempertahankan agar spermatozoa tidak mengalami kerusakan selama simpan beku, adalah dengan cara menambah semen dengan medium tertentu sebelum dilakukan simpan beku. Medium simpan beku spermatozoa umumnya mengandung buffer dan cryoprotectant. Medium TES-Tris yolk citrat (TESTYC) merupakan medium yang sering digunakan pada simpan beku spermatozoa. Medium tersebut merupakan medium yang dapat mempertahankan motilitas spermatozoa post thawing relatif tinggi, oleh karena itu medium tersebut direkomendasikan sebagai cryoprotective medium untuk simpan beku spermatozoa manusia. Medium TESTYC mengandung TES-Tris dan Nasitrat sebagai buffer, gliserol sebagai cryoprotectant, kuning telur, dan fruktosa sebagai sumber energi. TES-Tris merupakan buffer yang berfungsi baik pada pre-freeze maupun postthawing. TES-Tris buffer dapat mengikat ion hidrogen pada medium sehingga mempercepat proses dehidrasi. (Weidel \& Prins, 1987).

Gliserol dalam medium merupakan cryoprotectant yang dapat melindungi spermatozoa dari kerusakan selama proses pendinginan berlangsung (Winarso \& Hinting, 1999). Pada medium simpan beku tanpa gliserol, hasil thawing yang didapat menunjukkan survival spermatozoa yang lebih rendah dibanding medium yang mengandung gliserol. Kondisi tersebut menunjukkan bahwa gliserol dalam medium simpan beku dapat berfungsi sebagai cryoprotectant dan sangat penting untuk mempertahankan survival spermatozoa. Pada proses thawing, simpan beku dalam medium tanpa gliserol menyebabkan terjadinya penurunan recovery of motile spermatozoa oleh karena terjadi penurunan survival spermatozoa. Dengan adanya gliserol sebagai cryoprotectant dalam medium, motilitas postthawing akan lebih terjaga (Prins \& Weidel, 1986).

Kuning telur dalam medium TES-TYC bukan merupakan cryoprotectant tetapi berfungsi mempertahankan fluiditas membran sel (Mortimer,1994). Pada kuning telur terdapat lemak yang antara lain tersusun atas gliserol dan kolesterol. Komponen tersebut diketahui dapat mempertahankan integritas sel pada saat terjadi penurunan suhu. (Mortimer,1994; Albert et al.,1994 ; Hafez, 1968). Kuning telur ayam merupakan salah satu komponen medium TESTYC (Prins \& Weidel, 1986). Struktur dan fungsi spermatozoa post freezing yang disimpan dengan medium TES-TYC lebih baik dibanding struktur dan fungsi spermatozoa post freezing yang disimpan dengan gliserol saja (Hallack et.al.,1996). Kuning telur ayam merupakan salah satu komponen medium TES-TYC yang bersama dengan gliserol berfungsi sebagai protektor membran (Mortimer,1994). Kandungan lemak 
dalam kuning telur ayam 32,6\%, kuning telur bebek 35,2\% sedangkan kuning telur angsa $36 \%$. Gliserida merupakan komponen tertinggi penyusun lemak kuning telur. Gliserida pada kuning telur tersusun atas gliserol dan asam lemak (Romanoff \& Romanoff, 1963), Gliserol merupakan cryoprotectant yang paling umum pada simpan beku semen manusia (Mortimer,1994). Di dalam lemak kuning telur juga terdapat kolesterol yang dapat mempertahankan fluiditas membran sel sehingga dapat mencegah kerusakan sel akibat penurunan suhu (Alberts et al., 1998 ; Hafez,1968).

\section{BAHAN DAN METODE}

Penelitian ini dilakukan di Laboratorium Andrologi Rumah Sakit Telogorejo Semarang. Penelitian ini merupakan penelitian eksperimental yang dilakukan di laboratorium yang merupakan percobaan dengan rancangan dasar menggunakan rancangan acak lengkap (RAL) (Munawar, 1995)

Sampel dalam penelitian ini adalah semen yang berasal dari pria dewasa, dengan kriteria inklusi yang diterapkan pada penelitian ini adalah : volume, leukosit, $\mathrm{pH}$, viscositas semen, serta jumlah, motilitas dan vitalitas spermatozoa sesuai kriteria yang diterapkan oleh WHO (Anonim,1999). Semen diperoleh dari 30 pria dewasa, semen yang berasal dari satu orang dibagi menjadi dua kelompok perlakuan.

Variabel penelitian ini adalah motilitas dan vitalitas spermatozoa, yang diamati sebelum dan sesudah simpan beku (Mortimer, 1994 ; Spano et. al., 1999). Pengujian ketepatan metode simpan beku dilakukan dengan menghitung Cryosurvival Factor (Mortimer, 1994).

Cara penelitian ini meliputi cara pembuatan medium TEST-Tris yolk citrat (TESTYC) sesuai metode Winarso \& Hinting, 1999 ; Prins \& Weidel 1986 ; Mortimer, 1994. Cara penyimpanan semen (semen cryopreservation) sesuai metode Winarso \& Hinting (1999). Cara penuaian (thawing) sesuai dengan metode Weidel \& Prins (1987).

Data hasil penelitian diuji pola distribusinya dengan menggunakan uji Kolmogorov-Smirnov, dan dilanjutkan dengan uji homogenitas variansi. Hasil uji pola distribusi menunjukkan semua data mengikuti pola distribusi normal dan variansinya homogen maka dilakukan uji statistik dengan menggunakan analisis parametrik dengan menggunakan uji Anova dengan uji lanjut Duncan (Munawar, 1995 ; Santosa, 1999)

\section{HASIL DAN PEMBAHASAN}

Tabel 1. Hasil penghitungan rerata motilitas dan vitalitas spermatozoa sebelum dan setelah simpan beku (dalam \%)

\begin{tabular}{cccc}
\hline Medium & $\begin{array}{l}\text { Motilitas Pre } \\
\text { Freezing }\end{array}$ & $\begin{array}{l}\text { Motilitas Post } \\
\text { Freezing }\end{array}$ & CSF \\
\hline A & $58,70 \pm 4,59^{\mathrm{a}}$ & $35,81 \pm 3,06^{\mathrm{b}}$ & $60 \pm 3,44$ \\
\hline B & $58,70 \pm 4,59^{\mathrm{a}}$ & $33,04 \pm 2,79 \mathrm{c}$ & $56 \pm 3,87$ \\
\hline C & $58,70 \pm 4,59^{\mathrm{a}}$ & $31,21 \pm 2,79 \mathrm{~d}$ & $53 \pm 4,42$ \\
\hline \multicolumn{5}{c}{} \\
\hline Medium & VitalitasPre & Vitalitas Post & CSF \\
& Freezing & Freezing & \\
\hline A & $78,70 \pm 6,22^{\mathrm{e}}$ & $48.01 \pm 4,35^{\mathrm{f}}$ & $61 \pm 5,74$ \\
\hline B & $78,70 \pm 6,22^{\mathrm{e}}$ & $45,18 \pm 3,37 \mathrm{~g}$ & $58 \pm 4,48$ \\
\hline C & $78,70 \pm 6,22^{\mathrm{e}}$ & $43,18 \pm 4,37^{\mathrm{h}}$ & $55 \pm 4,74$ \\
\hline
\end{tabular}

Data yang diikuti superscrip yang sama menunjukkan berbeda tidak nyata. Data yang diikuti superscrip yang berbeda menunjukkan berbeda nyata.

Hasil penelitian menunjukkan Cryosurvival Factor semua variabel di atas $50 \%$. Dengan demikian dapat dipastikan bahwa penurunan motilitas dan vitalitas postfreezing setelah simpan beku bukan disebabkan kesalahan prosedur kerja tetapi dampak dari perlakuan.

Kuning telur dalam medium TES-TYC berfungsi mempertahankan fluiditas membran sel (Mortimer,1994). Pada kuning telur terdapat lemak yang antara lain tersusun atas gliserol dan kolesterol. Komponen tersebut diketahui dapat mempertahankan integritas sel pada saat terjadi penurunan suhu (Mortimer,1994 ; Hafez, 1968 ; Albert et al. 1994)

Fluiditas merupakan hal penting secara biologis bagi membran sel (Albert et al. 1994). Aktivitas enzim dan proses transport melalui membran akan terhenti bila struktur bilayer menjadi kaku. Fluiditas lipid bilayer membran sangat tergantung pada temperatur dan komposisinya. Pada temperatur rendah, rantai phospholipid pada membran berubah dari fase sol menjadi fase gel, perubahan tersebut disebut 
sebagai fase transisi. Hal ini menyebabkan membran sulit membeku. Disamping itu adanya ikatan ganda cis yang membentuk lekukan pada rantai hidrokarbon dan membuat rantai hidrokarbon sulit bersatu, sehingga membran tetap fluid pada temperatur rendah. Disamping phospholipid, lipid bilayer pada membran sel juga tersusun atas kolesterol. Pada konsentrasi rendah kolesterol menyebabkan membran sel menjadi kurang fluid tetapi pada konsentrasi yang tinggi, kolesterol mencegah rantai karbon bergabung sehingga mencegah membran menjadi kaku (rigid) (Albert et al. 1994 ; Anonim, 2000)

Keberadaan kuning telur dalam medium TES-TYC akan menyebabkan medium tersebut mengandung kolesterol. Keberadaan kolesterol pada kuning telur menyebabkan kandungan kolesterol pada medium TES-TYC menjadi tinggi sehingga fluiditas membran dapat terjaga pada suhu rendah. Dengan demikian fluiditas membran dapat bertahan lebih lama pada proses penurunan suhu berlangsung, sehingga dehidrasi dapat berlangsung semaksimal mungkin. Hal tersebut mengakibatkan berkurangnya pembentukan kristal es intrasellular. Dengan berkurangnya kristal es intrasellular maka pembentukan kristal es yang besar pada saat thawing juga berkurang, kerusakan sel juga berkurang.

Komponen terbesar penyusun lemak kuning telur adalah gliserida yang merupakan gabungan antara gliserol dan asam lemak. Kandungan gliserol pada kuning telur angsa paling tinggi diikuti gliserol pada kuning telur bebek, dan terendah gliserol pada kuning telur ayam. (Romanoff \& Romanoff 1963), Dengan demikian maka kandungan gliserol medium TES-TYC dengan kuning telur angsa adalah yang tertinggi dan diikuti medium TES-TYC dengan kuning telur bebek, medium TES-TYC dengan kuning telur ayam.

Sebagai cryoprotectant, gliserol mempunyai tiga sifat, yaitu dapat melewati membran secara pasif, dapat menggantikan air, pada konsentrasi tinggi bersifat toksik (Henry et al.,1993). Toksisitas gliserol dapat dikurangi dengan menurunkan konsentrasi gliserol dalam medium. Penurunan konsentrasi gliserol dari 7,5 \% sampai $5 \%$ dapat meningkatkan motilitas spermatozoa post thawing (Critzer et al., 1988). Konsentrasi gliserol dalam medium TES-TYC adalah $6 \%$ (Weidel \& Prins, 1987).

Hasil penelitian menunjukkan motilitas dan vitalitas spermatozoa post freezing yang disimpan dengan medium TES-TYC dengan kuning telur ayam tertinggi bila dibandingkan dengan medium TES-TYC dengan kuning telur bebek maupun angsa. Secara teoritis medium TES-TYC dengan kuning telur angsa merupakan medium yang dapat mempertahankan motilitas spermatozoa post freezing tertinggi, sedangkan medium TES-TYC dengan kuning telur ayam mempertahankan motilitas spermatozoa post freezing yang terendah. Kondisi tersebut kemungkinan disebabkan konsentrasi gliserol dalam medium TES-TYC dengan kuning telur bebek dan medium TES-TYC dengan kuning telur angsa cukup tinggi sehingga melampaui batas toksisitas gliserol, sedang gliserol dalam medium TES-TYC dengan kuning telur ayam kemungkinan berada pada konsentrasi optimum dan tidak melampaui batas toksisitas gliserol. Berdasarkan hal tersebut dapat dipahami bila medium TES-TYC dengan kuning telur ayam mempertahankan motilitas spermatozoa post freezing tertinggi.

Defect aksonema mempengaruhi vitalitas spermatozoa. Bila hal tersebut terjadi pada spermatozoa, maka spermatozoa tersebut akan tetap vital (viable) tetapi immotil. Kematian spermatozoa itu sendiri juga merupakan hal yang mempengaruhi vitalitas spermatozoa. Persentase proporsi vitalitas spermatozoa yang tinggi tetapi immotil menunjukkan adanya kerusakan struktural pada flagella (Anonim, 1999).

\section{KESIMPULAN}

Pada penelitian ini dapat disimpulkan bahwa kuning telur ayam merupakan jenis kuning telur yang paling sesuai sebagai bahan baku medium simpan beku semen TES-TYC.

\section{DAFTAR PUSTAKA}

Alberts, B., D. Ray, J. Lewis, K. Raff, K. Roberts, J.D. Watson. 1994 Molecular Biology of the cell. $3^{\text {rd }}$ Edition. Garland Publishing Inc. New York. pp 483 - 502.

Anonim. 1999. WHO Laboratory Manual for the examination of human semen and spermcervical mucus interaction. $4^{\text {th }}$ Ed. 
Cambridge University Press. United Kingdom.

Anonim.2000. Cell Membrane. http://www.altavista.com.

Critzer, J.K., A.R. Huse-Benda, D.V. Aaker, B.W. Arneson, G. David Ball. 1988. Cryopreservation of human spermatozoa. III. The Effect of Cryoprotectant on Motility. Fertil Steril. : 50(2) : 314-320.

Constatinides, P.1993. General Pathology. Appleton \& Lange. pp39-42 Connecticut

Girraud, M.N., C. Motta, D. Boucher, and G. Grizard. 2000. Membrane fluidity predicts the outcome cryopreservation of human spermatozoa. J. Hum. Reproduction. 15 (10) : 2160 - 2164.

Hafez, E.S.E. 1968. Reproduction in Farm Animals. $2^{\text {nd }}$ Ed. Lea \& Febiger. Philadelphia. pp 51 - 56.

Hallack J., R.S. Sidhu, A.J. Thomas Jr. 1996. Effect of test yolk buffer and glycerol cryoprservation on human speramtozoa morphology and function. ASRM Abstracts.

Henry, M.A., E.E. Noiles, D. Gao, P. Mazur, J.K. Critzer. 1993. Cryopreservation of human spermatozoa. IV. The effect of cooling rate and warming rate on the maintenance of motility, plasma membrane integrity, and mitochondrial function. Fertil. Steril. 60 (5) : $911-917$.

Johnson M., B. Everitt, 1988. Essential Reproduction. $3^{\text {rd }}$ Edition.Oxford. Blackwell scientific Publ. : 52-62.

Mazur P. 1977. The Role of intracellular Freezing in the Death of Cells Cooled at Supraoptimal Rates. J. Cryobiology. 14 : 251-272

Mortimer D. 1994. Practical laboratory andrology. University Press. New York Oxford pp 301 -320 .
Munawar. Biometri II. 1995. Jurusan Biologi FMIPA UNSRI. Palembang.

Nieschlag, E., \& H.M. Behre. 1996 Andrology. Male Reproductive Health and Dysfunction. Springer Publ. Berlin. pp 65 $-105$

Polcz T.E., J.B. Stronk, G.B. Huszar. 1996. Repeated Cryopreservation of Ejaculated Human Spermatozoa, Recovery and Maintenance of Sperm Motility and Viability.. ASRM Abstract.

Prins, G.S. \& L. Weidel. A. 1986. Comparative study of buffer system as cryoprotectant for human spermatozoa. Fertil. Steril. 46:147- 149.

Romanoff A.L., Anastasia J. Romanoff. 1963. The avian egg. $2^{\text {nd }}$ Edition. New York. John Willey \& Sons Inc. $311-343$.

Santoso Singgih. SPSS (Statistical Product and Service Solution). 1999. Jakarta : PT Elex Media Komputindo, 300 - 380.

Spano M, E. Cordell, G. Leter, F. Lombardo, A. Lenzi, and L. Gandini. 1999. Nuclear chromatin variations in human spermatozoa undergoing swim-up and cryopreservation evaluated by the flow cytometric sperm chromatin structure assay. Molecular. $J$. Human Reproduction. 5 (1) : 29 - 37.

Weidel L., and G.S. Prins. 1987. Cryosurvival of Human Spermatozoa Frozen in Eight Different Buffer Systems. J. Androl. $8: 41$ $-47$.

Wetzels, A.M.M. 1996. IVF Laboratory aspects of in-vitro fertilization. N.V. Organon. Netherlands. pp $228-240$.

Winarso, H. \& A. Hinting. 1999. Simpan beku sperma manusia. Post graduate course Penatalaksanaan infertilitas pria dan analisis semen. FK Unair. Surabaya. 